\title{
Transit potential of Republic of Belarus: current state and development prospects
}

\author{
Vasylchenko Anastasiia ${ }^{1, *}$ \\ ${ }^{1}$ Polessky State University, Economical Department, Dneprovskoy flotilii, 23, 225710, Pinsk, Belarus
}

\begin{abstract}
The article is devoted to the development of transport infrastructure, the problems of logistics and transit potential of the Republic of Belarus. The review analysis of the logistics potential is given taking into account its development prospects. The monitoring of the dynamics of transit revenues was carried out, relevant conclusions are given, recommendations on its increase are presented. The article presents the dynamics of cargo transportation by type of transport indicating the structural elements of logistics centers and their localization in the Republic of Belarus. Efficiency indexes of the development of the country's logistic system according to the World Bank are analysed. Reasonable conclusions are given.
\end{abstract}

In the context of globalization and integration processes, there is an active development of foreign economic relations between countries, strengthening of trade cooperation, growth in foreign trade and transit traffic, improvement of the technical level of transport system and the quality of services provided. All these intensify and increase the role of transport system, which becomes the basis for the formation of domestic as well as international markets, thus providing the foundation for market economy processes in the world. The Republic of Belarus has an advantageous economic, geographical and geopolitical position, being located at the crossroads of the developing world business clusters - the countries of the European Union, the Russian Federation, the Asia-Pacific region (with its promising development of the new Silk Road). This will help to develop the logistics system, improve the transport infrastructure in the context of increasing the transit potential of the country in the international arena.

The following scientists were involved in the development of the transport infrastructure, logistics and transit potential of the Republic of Belarus: M. B. Gubsky, T. R. Kisel, R. B. Ivut [1], I. A. Elova, P. G. Nikitenko, I. I. Poleshchuk, A. A. Evsyuk, V. V. Yasinsky, A. V. Chernovalov, etc. However, many aspects have not been studied sufficiently due to ongoing changes in the global market economy, absence of the uniform approach to the definition of the main concepts, different basic approaches to the assessment of the transit potential.

In recent years, there have been significant changes in foreign markets due to geopolitical processes, socio-economic transformations and the reorientation of the major

\footnotetext{
${ }^{1}$ Corresponding author: vasichenko.2012@inbox.ru
} 
market players from Western (the European Union) to Eastern countries (Asia-Pacific region). To analyze the transport system and its development prospects, together with the expansion of international trade relations of the Republic of Belarus, let's define the concept of "transit potential“. In some sources it is defined as "transportation of goods or the movement of passengers from one place of the country or region to another through the third place on its way or from one point to another through intermediate points" [2]. Transshipment operations can be carried out in the transit territory, but, according to the author, they are not a decisive factor in defining this concept. At the same time, the underlying characteristic of transit is the location of the final point of delivery outside the transit territory. The ability of the local transport infrastructure to meet the needs of international transit operations for the movement of goods and passengers plays a huge role in transit.

The work on the development of the logistics potential of the Republic of Belarus was carried out under the Development Program of the Logistics System of Belarus for 20082015. In the course of its implementation, 20 logistics centers with a total area of more than 400 thousand square meters were built, over 4.6 million Belarusian rubles (BYN) of investments were attracted, more than 4.6 thousand jobs were created [3].

The volume of logistics services rendered in the Republic of Belarus in 2015 amounted to 1498 billion BYN, including 981.6 billion BYN provided by transport and logistics centers, wholesale and logistics as well as trade and logistics centers - 115.9 billion BYN. Revenues from logistics services for handling of transit cargo on the territory of the Republic of Belarus amounted to 462 billion BYN.

Experts predict that taking into account the current trends in the development of the logistics system, the volume of logistics services rendered in the Republic of Belarus will increase by a factor of 1.5 by 2020 compared to 2015 and will be about 2258 million BYN. At the same time, the total storage space of logistics centers of various functionalities will increase by a factor of 1.64 by 2020 and will amount to more than 656 thousand square meters [3]. Such forecast data are given in the Development Program of the Logistics System and Transit Potential for 2016-2020.

The income dynamics from the transit of the Republic of Belarus is very unstable and depends on a number of factors: the political situation, the dynamics of prices and currency fluctuations, the state of the transport and logistics system and the development of its potential, the economic situation of the shipping countries. At the same time, revenues from transit of the Republic of Belarus from 2006 to 2013 steadily increased, despite the Global economic crisis of 2009. However, since 2014 this trend has not persisted, the revenues have declined significantly. This happened for objective reasons, due to the introduction of economic sanctions by the United States and the European Union against the Russian Federation, as well as the trade embargo on a number of goods from the European Union countries. In 2016, the revenues fell to $\$ 1200$ million, which is a record low. This happened due to unfavourable geo-economic and geopolitical factors prevailing in the global market. The Republic of Belarus depends on these factors owing to its geographical position and its location at the crossroads of world transportation routes. Nevertheless, in 2011-2015 transit revenues amounted to $\$ 13.9$ million, which is almost $30 \%$ as high as compared to 2006-2010. It is still too early to judge by 2016-2020 indicators because of the need to end the reporting period.

In the item "Revenues from transit", the statistics of the Republic of Belarus includes the revenues from the transit of oil, natural gas and the revenues from transit in the field of transport. Meanwhile, the leading place in the structure of these revenues is occupied by the revenues from the transit of energy carriers and from the movement of transit cargo by rail. In 2015, the profits from the export of communication services amounted to $\$ 5.7$ million; from the carriage of goods by rail $-\$ 378.3$ million; from the transportation of passengers 
by rail $-\$ 22$ million; from the maintenance of transit flights by air $-\$ 73.0$ million; from fees on toll roads $-\$ 117.2$ million; from the tolls of motor vehicles of foreign countries on public roads $-\$ 11.2$ million, and $\$ 1.1$ million from foreign heavy and/or large vehicles [4]. It is estimated that in 2016 the revenues from oil transit amounted to $\$$ 150.5 million, from gas transit $-\$ 476.7$ million, from transit in the transport sector (except for pipeline) — $\$ 879.2$ million [5].

More than 13 thousand organizations of various forms of ownership and more than 17 thousand individual entrepreneurs work in the transport sphere of Belarus, employing about 275 thousand people $-6.2 \%$ of the total number of employed in the country's economy. On the territory of the Republic of Belarus there are about 100 thousand $\mathrm{km}$ of roads, 5.5 thousand $\mathrm{km}$ of public railways, of which one fifth is electrified, as well as 1.7 thousand $\mathrm{km}$ of inland waterways. In terms of freight turnover of road and rail transport per capita (6.88 thousand ton-km), Belarus is ahead of such European countries as Germany (5.22 thousand ton-km), Belgium (3.6 thousand ton-km), France (2.9 thousand tons-km), Italy (2.15 thousand tons-km) [6].

The state policy of the Republic of Belarus also promotes the development of logistics, as evidenced by the following regulatory legal acts: the State Development Program of the Transport Complex of the Republic of Belarus for 2016-2020, the Program of Social and Economic Development of the Republic of Belarus for 2016-2020, the Resolution of the Council of Ministers dated 12.05.2016 №372 "On Priority Activities (Sectors of the Economy) for Investments“, etc. The latter outlines the priority sectors of the economy for investments, including the development of the logistics system, as well as rail and air transport. There are five standards for the development of logistics infrastructure in the Republic of Belarus: SSRB 2047-2010 "Logistics activities. Terms and definitions“, SSRB 2046-2010 "Transport and logistics center. Requirements for technical equipment and freight forwarding services“, SSRB 2133-2010 "Classification of warehouse infrastructure“, SSRB 2306-2013 "Logistics services. General requirements and certification procedure“, SSRB 2345 "Logistics activities. Requirements for professional competence of logistics service personnel and certification procedure“.

According to statistics, the dynamics of goods carriage by types of transport in the Republic of Belarus is as follows (Figure 1).

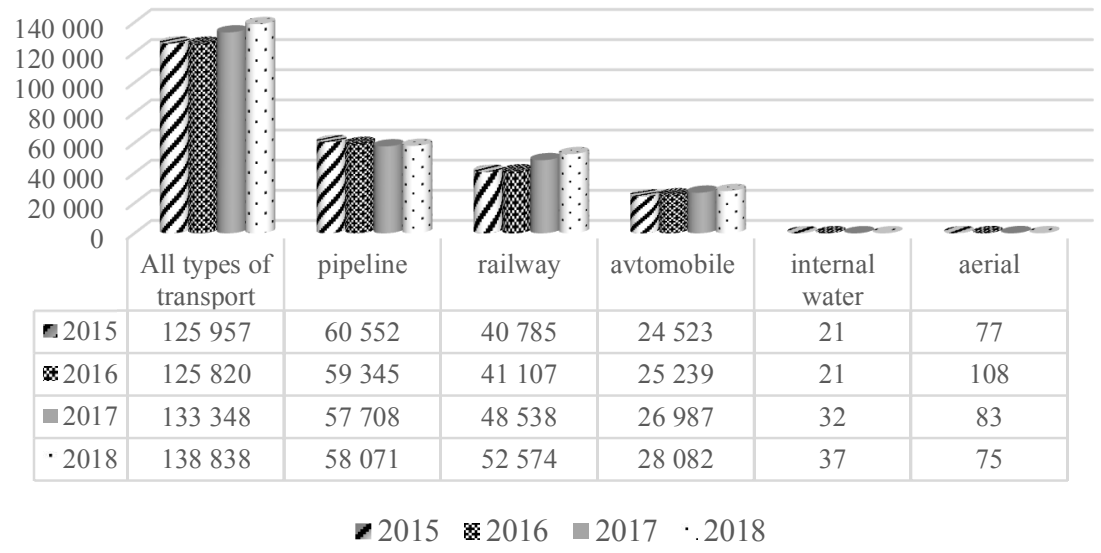

Fig. 1. The transportation of goods by different types of transport (2015-2018), million tons [7]. 
The Development Program of the Transport Complex of the Republic of Belarus for 2011-2015 resulted in the building of 20 logistics centers with a total area of 400 thousand square meters. The implementation of these projects called for more than 4.6 trillion BYN, 4.6 thousand new jobs were created. The volume of logistics services rendered in 2015 amounted to 1498 billion BYN, of which: transport and logistics centers - 981.6 billion BYN, wholesale and logistics as well as trade and logistics centers -115.9 billion BYN. The revenues from logistics services for handling transit cargo in Belarus amounted to 462 billion BYN [8].

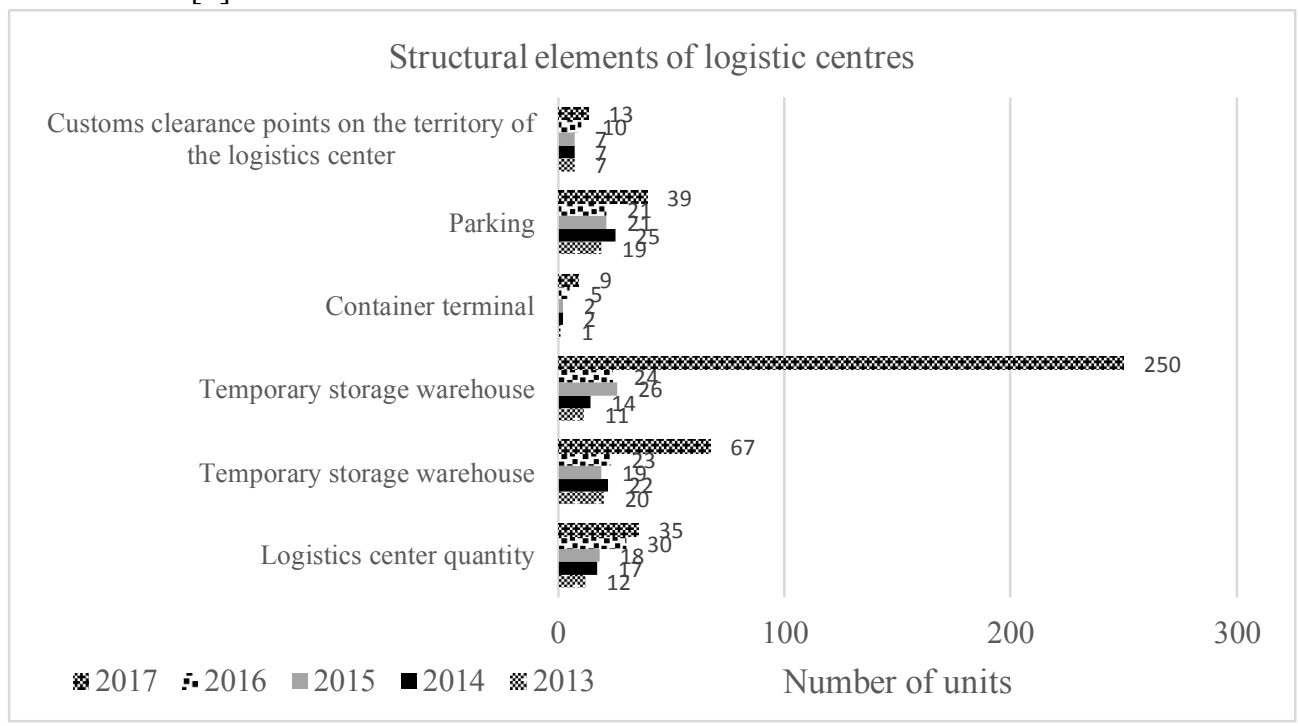

Fig. 2. Structural elements of logistics centers (2013-2017), units [9].

The dynamics of changes in the structural elements of logistics centers can be seen in Figure 2. On the whole, in the Republic of Belarus there is a tendency to increase their number (in 2013 there were12 units, in 2018 - 48 units), the growth rate is $400 \%$. Altogether, this is a positive trend, indicating the increase in capacity in the field of logistics infrastructure. Furthermore, there is a positive trend in the context of the structural elements of logistics centers: the number of temporary storage warehouses is increasing (the growth rate of 2017 by 2013 is $335 \%$ ); the number of public warehouses from 2016 to 2017 increased by a factor of 4.6; the number of container terminals increased by a factor of 9 compared to 2013; the number of parking lots for the same period increased by 20 units, and the number of customs control points doubled.

Experience shows that for the successful implementation of the transit potential of the Republic, not only the developed transport infrastructure is important, but also the optimal location of logistics centers near the main transport flow routes, which allows for timely, efficient and high quality logistics services. It can be seen [9] that the volume of logistics services provided by logistics centers is growing (it increased by 37.6 million BYN in 2017 compared to 2016).

The volume of logistics services for handling transit cargo in the Republic of Belarus for 2016-2017 increased by 32.3 percentage points, and the volume of freight forwarding services - by 51.9 percentage points respectively.

The analysis of the range of services provided by logistics centers (on the terms of voluntary certification) showed that these logistics centers provide no more than 15 of the 88 possible types of services established by the standard SSRB 2306-2013, which is certainly an obstacle to the development of foreign trade relations. Besides, a number of 
negative trends have been revealed in connection with the changes in world markets, namely: under the influence of external political and economic factors, Russian export cargo is reoriented from the ports of Lithuania, Latvia and Ukraine to its own ones. In general, changes in the foreign trade policy of the Russian Federation are due to the cooperation change from Western countries (EU countries) to the countries of the AsiaPacific region and China. There is a trend for the Russian ruble devaluation. While $92 \%$ of transport by rail is export-import cargo of Russia and Kazakhstan, this factor is undoubtedly a negative trend for the expansion of the use of the transit potential of the Republic of Belarus.

Commodity flows passing through the territory of the Republic of Belarus are mainly formed at the expense of the EU and the Asia-Pacific countries. The change in global market processes leads to the redistribution of these flows and their reorientation from the Central European to the South European direction. Accordingly, the use of the transit potential of Belarus depends on the demand for certain types of products, including timber, mineral fertilizers, oil and petroleum products, as well as ferrous metals. The key point here is the low competitiveness of the existing logistics system along with unfavourable external conditions: unequal conditions for logistics centers within the Eurasian Economic Union, high competition with European Union companies, and complexity of technical regulations.

In 2007, the World Bank, in order to determine the efficiency of the country's logistics system, developed a methodology for calculating the LPI index (logistics performance index - LPI). This index is measured every two years, the results of the study were published in 2007, 2010, 2012, 2014, 2016, 2018. In 2010, the Republic of Belarus did not participate in the assessment. The LPI methodology includes a five-point scale of six evaluation criteria and calculating the average index value for each country.

The following evaluation criteria are used:

- efficiency of customs clearance;

- quality of logistics transport information technology infrastructure;

- simplicity and availability of international shipments;

- level of logistics quality and competence;

- tracking and tracing of international delivery;

- timeliness of deliveries.

The results of the research are shown in table 1.

Table 1. LPI index of the Republic of Belarus in 2007-2018 [10].

\begin{tabular}{|l|l|l|l|l|l|l|l|l|l|l|}
\hline \multirow{2}{*}{$\begin{array}{l}\text { The evaluation } \\
\text { criterion }\end{array}$} & \multicolumn{9}{|c|}{ The values by year } \\
\cline { 2 - 13 } & \multicolumn{2}{|c|}{$\mathbf{2 0 0 7}$} & \multicolumn{2}{c|}{$\mathbf{2 0 1 2}$} & \multicolumn{2}{c|}{$\mathbf{2 0 1 4}$} & \multicolumn{2}{c|}{$\mathbf{2 0 1 6}$} & \multicolumn{2}{c|}{$\mathbf{2 0 1 8}$} \\
\cline { 2 - 12 } & score & rank & score & rank & score & rank & score & rank & score & rank \\
\hline Customs & 2,67 & 50 & 2,24 & 121 & 2,55 & 87 & 2,06 & 136 & 2,35 & 112 \\
\hline Infrastructure & 2,63 & 54 & 2,78 & 65 & 2,55 & 86 & 2,19 & 135 & 2,44 & 92 \\
\hline $\begin{array}{l}\text { International } \\
\text { transport }\end{array}$ & 2,13 & 127 & 2,58 & 107 & 2,74 & 91 & 2,62 & 92 & 2,31 & 134 \\
\hline $\begin{array}{l}\text { Quality } \\
\text { competence }\end{array}$ & 2,13 & 120 & 2,65 & 89 & 246 & 116 & 2,32 & 125 & 2,64 & 85 \\
\hline Cargo tracking & 2,71 & 166 & 2,58 & 98 & 2,51 & 113 & 2,16 & 134 & 2,54 & 109 \\
\hline $\begin{array}{l}\text { Timeliness of } \\
\text { deliveries }\end{array}$ & 3,00 & 78 & 2,87 & 114 & 3,05 & 93 & 3,04 & 96 & 3,18 & 78 \\
\hline LPI index & 2,53 & 74 & 2,61 & 91 & 2,64 & 99 & 2,40 & 120 & 2,57 & 103 \\
\hline
\end{tabular}

As can be seen from table 1, in 2018 the Republic of Belarus took 103rd place from 160 countries, in 2016 it was 120th. The statistics of the previous years show that in 2007 it occupied 74th place, in 2012 - 91st place, in 2014 - 99th place, which points to a large role of state support in the development of the logistics system of the Republic of Belarus. For 
comparison, in 2016 Russia ranked 99th, Kazakhstan - 77th, Ukraine - 80th, Lithuania 29th, Latvia - 43rd, Poland - 33rd, Germany - 1st. In 2018 Germany took first place, Russia moved to the 75th place, Kazakhstan -71 st, Ukraine -66 th, Lithuania -54 th, Latvia -70 th, and Poland rose its position to the 28th [10].

The method of calculating this index is not perfect, which is acknowledged by its developers from the World Bank. It does not take into account the peculiarities of the geographical location, the access to the sea, the area of the country, etc. In addition, it is based on a survey of international logistics companies, while the opinion of consumers of logistics services is not taken into consideration. All in all, the market of logistics services of the Republic of Belarus is developing steadily, but not as fast as that of the neighbouring countries.

Therefore, the degree of geopolitical risks depends on establishing favourable relations with the Russian Federation, the European Union, the Asia-Pacific region and China. A number of factors will contribute to the use of the country's transit potential: improvement of the existing legislation system, training highly qualified specialists in logistics, modernization of the logistics infrastructure, optimization of logistics centers location for the convenience of transport links, further development of information and communication technologies, introduction of innovative developments in the field of logistics.

\section{References}

1. R. B., Ivut, A.F., Zubritskiy, A. S., Development of transit potential of the Republic of Belarus in the conditions of formation of its transport and logistics system, 1(32), (2015)

2. T. F. Efremova, New dictionary of russuan language, (2000)

3. Logistics system and transit potential development program for 2016-2020, Retrieved from http: //www.baifby.com/page/60

4. A.D., Molokovich, V.A., Luksha, Results of implementation of the State program of development of transit potential of the Republic of Belarus for 2011-2015, Retrieved from http://elib.bsu.by/bitstream/pdf

5. Belarus loses the income from the transit, Retrieved from http://belaruspartisan.by/economic/349400/

6. Transport complex of Belarus, Retrieved from http://www.baif.by/stati/transportnyi-kompleksbelarusi/

7. Belarus in numbers. 2019: Statistical Yearbook. (2019). National statistical Committee of the Republic of Belarus. Minsk (2019)

8. How to save Belarusian transit, Retrieved from http: ://neg.by/novosti/otkrytj/kak-spastibelorusskij-tranzit/

9. Transport and communication in the Republic of Belarus. 2018: Statistical Yearbook. (2018). National statistical Committee of the Republic of Belarus. Minsk (2018)

10. URL: http://www.worldbank.org 